\title{
SEASONAL CHANGES IN BODY COMPOSITION IN AUSTRALIAN RULES FOOTBALLERS
}

\author{
Louise M. BURKE, BSc(Nutr), Dip Diet, R. A. GOLLAN, MEngSc, BA, BEd and R. S. D. READ, MAgrSc, PhD
}

Dept. Human Nutrition, Deakin University, Victoria, 3217, Australia

\section{ABSTRACT}

Anthropometric measurements were collected from a group of Australian Rules footballers at the start and end of the competitive season. Eighty-nine players were studied, drawn from a top level professional league team, a second level association team and an A-grade amateur association team. Changes in the physical profile of these players during the season were observed. A small but significant gain in fat-free body mass in the top level players was observed $10.9 \mathrm{~kg}$, $p<0.01$ ), but no change in body fat. The intermediate level players showed no significant change in body mass and a tendency toward a slight loss in body fat, while the lower level players showed a significant loss in body fat during the season $(1.8 \mathrm{~kg}, \mathrm{p}<0.001)$ without significant change in fat-free body mass.

Key words: Body composition, Seasonal changes.

\section{INTRODUCTION}

In a previous paper from this department (Burke et al, 1985) the anthropometric characteristics of Australian Rules footballers were presented. This physical profile described 119 players representing three levels of competition, at the beginning of the competitive season. It is recognised that the specific physical characteristics of the elite sportsmen reflect both inherited features as well as the conditioning effects of high level sport-specific training. Thus, it may be expected that the athlete's body composition and anthropometry will not remain static, but may alter according to the quantity, intensity and type of activity undertaken. This effect is best observed in sports that are played in seasons or cycles.

A number of studies have examined changes in the physical profiles of athletes at different stages of the year, e.g. pre- and post-season, peak-season and off-season. Most studies show an improvement in desirable characteristics (i.e. reduction in body fat, increased fat-free mass) after a period of training or competition (Muthiah and Sodhi, 1980; Thompson, 1959). One study of college wrestlers, measured peak- and post-season, found very little change in body composition (Kelly et al, 1978). This was thought to be a result of the year-round training undertaken by this study group. Another study found little chsirge in the physical profile of a group of track and field athletes after a five month season of competition (Thomas and Reilly, 1976). This could have been a result of initial high levels of conditioning, inefficient training regimes, or 'periodisation' within the season that was missed by the test spacing.

A study of cyclists over their competitive season indicated that body composition was maintained during this period (Perez, 1981). One study has reported a breakdown of lean body mass in a group of gymnasts and basketballers in the course of training, which was attributed to excessive training (Zhdanova and Parizkova, 1962).

The purpose of the present study was therefore to repeat

Address for correspondence:

Ms L. Burke

7/2 Grattan Street

Hawthorn, 3122

Victoria, Australia the anthropometric study of Australian Rules footballers (Burke et al, 1985) to observe any changes in body physique which occurred during a competitive season for groups of players of different standards.

\section{SUBJECTS AND METHODS}

The study was carried out over the last three weeks of the competitive season, a period of 18-20 weeks having elapsed since the first measurements. Observations were made on training nights, duplicating the conditions of the first study. Eighty-nine of the original 119 subjects were available for retesting, a number of players having left their clubs over the course of the season. Thus data was collected from 89 Australian Rules footballers from the senior team lists of three clubs at different levels of competition in Victoria.

Team 1: top level professional league $(n=39)$

Team 2: lower level professional association $(n=26$ )

Team 3: A-grade amateur association $(n=24)$

Personal data collected from the players included the number of senior games played throughout the season, number of games lost through injuries, and the hours and type of training per week over the last month. The footballers were also asked for a subjective view on any changes in their body composition over the season.

\section{Anthropometric Measurements}

The following measurements were taken, using the same techniques as in the previous study. Measurements were taken on the non-preferred side of the body, according to literature techniques (Durnin and Womersley, 1974). Harpenden skinfold calipers were used to take skinfold measurements:

Body Mass:

Circumferences: mid-upper arm, forearm, chest, midabdomen

Skinfold triceps, biceps, mid-axillary, chest, thicknesses: subscapular, supra-iliac, abdomen and anterior thigh.

Measurements from the previous study that were not expected to change (e.g. height and wrist diameter) were not repeated. Calculations were made of body mass index (weight divided by height squared) and of mid-arm muscle circumference (mid-upper arm circumference $-\pi \times$ triceps skinfold). 


\section{Calculation of Body Composition}

An estimate of body density was obtained using empirically derived equations from literature studies. The two prediction equations chosen in the first study were used again. The first (Durnin and Womersley, 1974) was derived from a study of a general male population, while the second (Wickkiser and Kelly, 1975) was derived from a study of American football players.

Durnin and Body density (B.D.) $=1.1631-0.0632$ log Womersley: (triceps skinfold + biceps skinfold + supra-iliac skinfold + subscapular skinfold).

Wickkiser $\quad$ B.D. $=1.10148-0.00118 \times$ mid-abdominal and Kelly: circumference $-0.00114 \times$ triceps skinfold $\times$ $0.00044+$ height.

The equation of Siri (1956) was used to convert body density to percentage body fat:

$$
\text { Percentage fat }=\left(\frac{4.95}{\text { Body density }}-4.50\right) \times 100
$$

\section{Results}

Personal characteristics of players at the end of the season are presented in Table I. A comparison of anthropometric measurements for all eighty-nine players tested at the beginning and end of season is shown in Table II; while Table III presents this comparison for ech team. Student's t-test (two-tailed) was used to test significance of differences.

For all players, there was a slight but non-significant increase in body mass over the season, but a significant fall in skinfold measurements; indicating a loss of body fat. The loss of body fat indicated by the equations of Durnin and Womersley, and Wickkiser and Kelly were 0.9 and 0.8 per
TABLE I

Characteristics of the players at the end of the season

\begin{tabular}{lcccccc}
\hline & $\begin{array}{c}\text { Team 1 } \\
(\mathrm{n}=39)\end{array}$ & \multicolumn{2}{c}{$\begin{array}{c}\text { Team 2 } \\
(\mathrm{n}=26)\end{array}$} & $\begin{array}{c}\text { Team 3 } \\
(\mathrm{n}=24)\end{array}$ \\
\hline & Mean & S.D. & Mean & S.D. & Mean & S.D. \\
Age (yrs) & 23.8 & 3.4 & 23.3 & 2.8 & 22.5 & 2.4 \\
Senior games & 8.2 & 6.3 & 10.1 & 7.0 & 11.5 & 5.6 \\
$\begin{array}{l}\text { Games missed } \\
\text { by injury }\end{array}$ & 4.6 & 4.0 & 2.3 & 1.9 & 3.2 & 4.0 \\
$\begin{array}{l}\text { Training (hr/wk) } \\
\text { rraing }\end{array}$ & 7.3 & 3.5 & 7.3 & 3.6 & 4.1 & 1.9 \\
\hline
\end{tabular}

TABLE ॥

Comparison of mean anthropometric measurements for all players at the start and end of the competitive season (means \pm S.E.M.). Signficance determined by two-tailed t-test

\begin{tabular}{|c|c|c|c|}
\hline & $\begin{array}{l}\text { Beginning } \\
\text { of season }\end{array}$ & $\begin{array}{l}\text { End } \\
\text { of season }\end{array}$ & Change \\
\hline Body mass (kg) & $78.9 \pm 0.7$ & $79.5 \pm 0.6$ & +0.6 \\
\hline $\begin{array}{l}\text { Circumferences }(\mathrm{cm}) \\
\text { mid-arm muscle } \\
\text { chest }\end{array}$ & $\begin{array}{l}28.2 \pm 0.2 \\
99.1 \pm 0.4\end{array}$ & $\begin{array}{l}28.3 \pm 0.2 \\
99.6 \pm 0.4\end{array}$ & $\begin{array}{l}+0.1 \\
+0.5\end{array}$ \\
\hline $\begin{array}{l}\text { Skinfolds (mm) } \\
\text { triceps } \\
\text { subscapcular } \\
\text { supra-iliac } \\
\text { abdomen }\end{array}$ & $\begin{array}{r}9.9 \pm 0.4 \\
10.1 \pm 0.2 \\
14.2 \pm 0.5 \\
12.5 \pm 0.5\end{array}$ & $\begin{array}{r}8.8 \pm 0.3 \\
9.2 \pm 0.2 \\
13.7 \pm 0.5 \\
11.7 \pm 0.4\end{array}$ & $\begin{array}{l}-1.1^{* * *} \\
-0.9^{* * *} \\
-0.5^{*} \\
-0.8\end{array}$ \\
\hline $\begin{array}{l}\text { Body fat (\%) } \\
\text { (Durnin \& Womersley) }\end{array}$ & $15.3 \pm 0.3$ & $14.4 \pm 0.3$ & $-0.9^{* * *}$ \\
\hline $\begin{array}{l}\text { Body fat (\%) } \\
\text { (Wickkiser \& Kelly) }\end{array}$ & $12.7 \pm 0.3$ & $11.9 \pm 0.3$ & $-0.8^{* *}$ \\
\hline Body fat (kg) & $11.1 \pm 0.3$ & $10.5 \pm 0.3$ & $-0.6^{* * *}$ \\
\hline
\end{tabular}

Significance: ${ }^{*} p<0.05 ;{ }^{* *} p<0.01 ;{ }^{* *} p<0.001$

TABLE III

Comparison of mean anthropometric and derived measurements at the start and end of the competitive season, by teams (means \pm S.E.M.). Significance determined by two-tailed t-test

\begin{tabular}{|c|c|c|c|c|c|c|}
\hline & \multicolumn{2}{|c|}{ Team 1} & \multicolumn{2}{|c|}{ Team 2} & \multicolumn{2}{|c|}{ Team 3} \\
\hline & Start & End & Start & End & Start & End \\
\hline Body mass (kg) & $\begin{array}{r}79.64 \\
\pm 1.08\end{array}$ & $\begin{array}{l}80.54^{* *} \\
\pm 0.06\end{array}$ & $\begin{array}{r}78.50 \\
\pm 0.95\end{array}$ & $\begin{array}{r}79.08 \\
\pm 0.93\end{array}$ & $\begin{array}{r}78.33 \\
\pm 1.43\end{array}$ & $\begin{array}{r}78.17 \\
\pm 1.40\end{array}$ \\
\hline $\begin{array}{l}\text { Circumferences }(\mathrm{cm}) \\
\text { mid-arm muscle }\end{array}$ & $\begin{array}{r}29.17 \\
\pm 0.29\end{array}$ & $\begin{array}{l}29.03 \\
\pm 0.27\end{array}$ & $\begin{array}{l}27.20 \\
\pm 0.31\end{array}$ & $\begin{array}{l}27.87^{* *} \\
\pm 0.20\end{array}$ & $\begin{array}{r}27.20 \\
\pm 0.46\end{array}$ & $\begin{array}{r}27.87 \\
0.40\end{array}$ \\
\hline chest & $\begin{array}{r}100.36 \\
\pm 0.71\end{array}$ & $\begin{array}{r}100.82 \\
\pm 0.68\end{array}$ & $\begin{array}{r}98.16 \\
\pm 0.66\end{array}$ & $\begin{array}{r}99.00 \\
\pm 0.71\end{array}$ & $\begin{array}{r}98.11 \\
\pm 0.73\end{array}$ & $\begin{array}{l}98.16 \\
\pm 0.65\end{array}$ \\
\hline $\begin{array}{l}\text { Skinfolds }(\mathrm{mm}) \\
\text { triceps }\end{array}$ & $\begin{array}{r}8.31 \\
\pm 0.42\end{array}$ & $\begin{array}{r}8.05 \\
\pm 0.40\end{array}$ & $\begin{array}{r}10.13 \\
\pm 0.64\end{array}$ & $\begin{array}{r}9.70 \\
\pm 0.54\end{array}$ & $\begin{array}{r}12.08 \\
\pm 1.14\end{array}$ & $\begin{aligned} & 8.87^{* * *} \\
\pm & 0.71\end{aligned}$ \\
\hline subscapular & $\begin{array}{r}9.65 \\
\pm 0.27\end{array}$ & $\begin{array}{l}9.00^{* * *} \\
\pm 0.26\end{array}$ & $\begin{array}{r}9.88 \\
\pm 0.40\end{array}$ & $\begin{aligned} & 9.04^{* * *} \\
\pm & 0.36\end{aligned}$ & $\begin{array}{r}11.17 \\
\pm 0.62\end{array}$ & $\begin{aligned} & 9.68^{* *} \\
\pm & 0.40\end{aligned}$ \\
\hline supra-iliac & $\begin{array}{r}12.39 \\
\pm 0.59\end{array}$ & $\begin{array}{r}13.02 \\
\pm 0.62\end{array}$ & $\begin{array}{r}14.18 \\
\pm 0.69\end{array}$ & $\begin{array}{r}13.11 \\
\pm 0.92\end{array}$ & $\begin{array}{r}17.03 \\
\pm 0.01\end{array}$ & $\begin{array}{r}15.48 \\
\pm 0.89\end{array}$ \\
\hline abdomen & $\begin{array}{r}11.22 \\
\pm 0.64\end{array}$ & $\begin{array}{r}11.39 \\
\pm 0.67\end{array}$ & $\begin{array}{r}11.71 \\
\pm 0.79\end{array}$ & $\begin{array}{r}11.48 \\
\pm 0.84\end{array}$ & $\begin{array}{r}15.36 \\
\pm 1.00\end{array}$ & $\begin{array}{l}12.52^{*} \\
\pm 0.82\end{array}$ \\
\hline $\begin{array}{l}\text { Body fat \% } \\
\text { (Durnin \& Womersley) }\end{array}$ & $\begin{array}{r}14.09 \\
\pm 0.36\end{array}$ & $\begin{array}{r}13.88 \\
\pm 0.41\end{array}$ & $\begin{array}{r}15.38 \\
\pm 0.48\end{array}$ & $\begin{array}{l}14.46^{*} \\
\pm 0.57\end{array}$ & $\begin{array}{r}17.26 \\
\pm 0.63\end{array}$ & $\begin{array}{l}15.14^{* * *} \\
\pm 0.54\end{array}$ \\
\hline $\begin{array}{l}\text { Body fat \% } \\
\text { (Wickkiser \& Kelly) }\end{array}$ & $\begin{array}{r}11.56 \\
\pm 0.35\end{array}$ & $\begin{array}{r}11.48 \\
\pm 0.38\end{array}$ & $\begin{array}{r}12.71 \\
\pm 0.66\end{array}$ & $\begin{array}{r}12.43 \\
\pm 0.57\end{array}$ & $\begin{array}{r}14.48 \\
\pm 0.78\end{array}$ & $\begin{array}{l}12.11^{* * *} \\
\pm 0.56\end{array}$ \\
\hline Body fat (kg) & $\begin{array}{l}10.28 \\
\pm 0.37\end{array}$ & $\begin{array}{r}10.27 \\
\pm 0.38\end{array}$ & $\begin{array}{r}11.09 \\
\pm 0.52\end{array}$ & $\begin{array}{r}10.69 \\
\pm 0.51\end{array}$ & $\begin{array}{r}12.51 \\
\pm 0.63\end{array}$ & $\begin{array}{l}10.70^{* * *} \\
\pm 0.49\end{array}$ \\
\hline Fat-free mass (kg) & $\begin{array}{r}69.36 \\
\pm 0.85\end{array}$ & $\begin{array}{l}70.27^{* * *} \\
\pm 0.86\end{array}$ & $\begin{array}{r}67.41 \\
\pm 0.68\end{array}$ & $\begin{array}{l}68.39 * \\
\pm 0.70\end{array}$ & $\begin{array}{r}65.83 \\
\pm 1.16\end{array}$ & $\begin{array}{r}67.47 \\
\pm 1.16\end{array}$ \\
\hline
\end{tabular}

Significance: ${ }^{*} p<0.05 ; *{ }^{*} p<0.01 ; * * p<0.001$ 
cent respectively, and were significant $(p<0.001$ and $\mathrm{p}<0.01$ ).

Examination of changes by team shows a small but significant increase in body mass $(0.9 \mathrm{~kg}, p<0.01)$ in Team 1 through the season, while the other teams showed no significant change in body mass. Changes in the skinfold measurements of Team 1 players were generally nonsignificant. Team 3 players recorded a significant decrease in mean skinfold thickness over the season, while Team 2 showed a smaller and non-significant decrease. Percentage body fat and weight decreased slightly in Team 1 through the season but the change was not significant. However, a slight and significant increase in fat-free mass $10.9 \mathrm{~kg}, \mathrm{p}<$ $0.001)$ was observed in this team. The estimated percentage body fat for Team 3 was observed to fall significantly, with a loss of $2.1 \%$, as estimated by the Durnin and Womersley equation ( $p<0.001)$ and a loss of $2.4 \%$ as estimated by the Wickkiser and Kelly equation. The loss of body fat corresponded to approximately $1.8 \mathrm{~kg}$. The small increase in fat-free mass in this team was found to be nonsignificant. The changes in the means for Team 2 players fell between those of the other two teams; there was a small decrease in percentage body fat, $0.9 \%$ by the Durnin and Womersley equation ( $p<0.05$ ), $0.3 \%$ by the Wickkiser and Kelly equation (non-significant), and an increase of $0.9 \mathrm{~kg}$ in the fat-free body mass $(p<0.02)$

\section{Discussion}

The competitive season for Australian Rules football generally lasts $20-26$ weeks, during the autumn and winter months. Games are played each weekend, and teams train two to five sessions per week depending on the level of involvement. The training emphasis may be on skills or match practice, but may also include heavy running and weight training sessions. In most top professional teams, pre-season training begins shortly after the end of the previous season and involves development of strength and endurance fitness. In lower grades of competition, there may be a long off-season period with training commencing a matter of weeks before the start of the competitive season.

In this study, anthropometric measurements were taken from a group of 89 Australian Rules footballers from three levels of competition, at the beginning and the end of the competitive season. It is realised that the inherent inaccuracy in taking measurements such as skinfold thicknesses requires that the results be interpreted with care (Zwiren et al, 1973). Consistent changes in overall physical characteristics were considered rather than single variables.

It was found that there was a small but significant gain in fat-free mass in Team 1 players but no change in body fat. Team 2 players showed no significant changes in body weight and a tendency towards a slight loss in body fat. Team 3 players showed a highly significant loss of body fat during the season, without a significant increase in fat-free mass.

These observations are consistent with the thesis that top level teams maintain a higher level of training during the pre-season and begin the season with a lower level of body fat. Any loss of body fat during the season is therefore minor, and the training regime produces an increase in muscle, giving an increase in fat-free mass. At the other end of the scale, the amateur team begins the season with more body fat, probably as a consequence of a lower level of activity in the 'off-season'. Training through the season thus produces a significant loss of body fat and a tendency for an increase in lean body mass. The intermediate team shows results in between the other two.

It is of interest to note that a change in body mass is not always a good indicator of a change in body composition. In football teams, the body mass of players is frequently monitored by coaching staff. It is recommended that other parameters such as skinfold measurements be used to provide more information, provided that an adequate technique is available for their measurement.

\section{References}

Burke, L. M., Read, R. S. D. and Gollan, R. A., 1985 "Studies of body composition in a group of Australian Rules Footballers of different grades". Brit.J.Sports Med. 19: 100-2.

Durnin, J. V. and Womersley, J., 1974 "Body fat assessed from total body density and its estimated skinfold thicknesses. Measurements on 481 men and women aged from 16 to 72 years". Brit.J.Nutr. 32: 77-97.

Kelly, J. M., Garney, B. A. and Kalm, K. K., 1978 "The effects of a collegiate wrestling season on body composition, cardiovascular fitness and muscular strength and endurance". Med.Sci.Sports 10: 119-24.

Muthiah, C. M. and Sodhi, H. S., 1980 "The effect of training on some morphological parameters of top ranking Indian basketball players". J.Sports Med. 20: 405-12.

Perez, H. R., 1981 "The effects of competitive road racing on the body composition, pulmonary function and cardiovascular system of sports cyclists". J.Sports Med. 21: 165-72.

Siri, W. E., 1956. Univ.Calif.Radiat.Lab.PubI. No. 3349, 1956.

Thomas, V. and Reilly, T., 1976 "Changes in fitness profiles during a season of track and field training and competition". Brit.J.Sports Med. 10: 217-22.

Thompson, C. W., 1959 "Changes in body fat estimated from skinfold measurements of varsity college football players during a season". Res.Quart. 30: 87-93.

Wickkiser, J. D. and Kelly, J. M., 1975 "The body composition of a college football team". Med.Sci.Sports 7: 199-202.

Zhdanova, A. G. and Parizkova, J., 1962 "Dinamika vesg I sostava tela basketbalister I gimnastov vissich razryadov". Teoriya I praktika fiz. Kult I sporta. 25: 27.

Zwiren, L., Skinner, J. S. and Buskirk, E. R., 1973 "Use of body density and various skinfold equations for estimating small reductions in body fatness". J.Sports Med. 13: 213-8. 